\title{
DESDOBRAMENTOS DE AFRODITE
}

\author{
Mirna Xavier Gonçalves - Universidade Federal de Pelotas \\ mirna.xavier@hotmail.com \\ Lauer Alves Nunes dos Santos - Universidade Federal de Pelotas \\ lauer.ufpel@gmail.com
}

\section{RESUMO}

A figura feminina sempre habitou a história da arte desde seus primórdios e dentre todas as mulheres retratadas houve deusas como Afrodite, divindade grega que regia o amor, a paixão, a beleza. Na pintura e na escultura, a imagem da deusa foi concebida por nomes como Botticelli, Ticiano, Bouguereau, Jacques Louis-David, e diversos outros que retratavam a deidade como uma mulher esguia, clara, de cabelos longos, jovem e nua. Além disso, a figura feminina da deusa é acompanhada de diversos outros símbolos que demonstram certos títulos relacionados a ela. O presente trabalho busca investigar quais seriam estes símbolos, como seria a representação canônica de Afrodite, como ela seria representada nas mídias atuais e o que caracterizaria a deusa nestas mídias. Através da análise iconográfica, iconológica e semiótica será possível realizar um estudo do que compõe necessariamente uma imagem de Afrodite.

Palavras-chave: Iconologia, Semiótica, Cultura Popular, Vênus, Mulher.

\section{INTRODUÇÃO}

Dentre os milênios de arte que permeiam museus ao redor do mundo existe uma figura em comum com centenas deles. Uma imagem que aparece desde o paleolítico e vai até o século XXI. Esta é a imagem da Vênus - chamada Afrodite, para os gregos que habita o imaginário universal desde tempos imemoriais, associando à sua figura conceitos imateriais como "fertilidade", "beleza", "abundância", "graça", "amor", "paixão" e outros inúmeros.

Apesar de carregarem o nome "Vênus", as estatuetas e representações femininas pré-helênicas não se relacionariam diretamente com a deusa Afrodite, mas sim com seus 
atributos citados anteriormente, relacionando assim características da deusa grega à noção de divindade feminina existente em períodos anteriores ao surgimento de registros associados à Afrodite.

Sua existência engloba a personificação de todos estes e muitos outros elementos que compõem a vasta gama de correlações da deusa, e para acessar cada um destes elementos usava-se na Grécia a noção de epíteto, que seriam títulos e atributos dados às divindades, entre elas Afrodite.

Contudo, de acordo com Giuliana Ragusa (2005), tais epítetos eram empregados de forma verbal e textual na liturgia grega, não sendo tão constantes se expressos em forma de imagem, ainda mais sem a presença de alguma espécie de legenda que denotaria aquela figura como "Afrodite Anadiomene" ou "Afrodite Citereia", por exemplo.

Tais epítetos surgem devido a características de culto apresentadas em determinadas regiões, fazendo com que assim surjam epítetos como "Afrodite Páfia", significando "da cidade de Pafos" (RAGUSA, 2005, p. 115), ou mesmo "Afrodite Ciprogênia", "nascida em Chipre", relacionando a deusa ao seu local de nascimento, de acordo com Hesíodo.

Determinados epítetos relacionam a deusa com atributos físicos ou descritivos das suas habilidades, como os citados por Ragusa, "Anadiomene" (erguida do mar), "Komaetho" (dos cabelos de fogo), "Bradínan" (esguia), "Morpho" (de belas formas), "Khrusion" (dourada), Antheia (das flores, da primavera), entre outros.

Estes epítetos, bem como os textos de onde emergem (que datam desde 800-480 a.C, a chamada era da lírica grega arcaica, por Giuliana Ragusa) fundamentariam inúmeras obras de arte que iriam da Grécia Arcaica, passando pelo Império Romano neste recebendo uma nova camada de significação a partir da visão da deusa Vênus chegando até os registros renascentistas, rococós, modernistas e contemporâneos de arte visual.

Desta forma, conforme a figura de Afrodite se consolida na história da arte, as imagens relacionadas a ela também passam pelo mesmo processo, criando assim uma imagética associada à deusa, seus atributos, domínios e estéticas, adicionando novos símbolos, cores e objetos ao âmbito da divindade. 


\section{A MITOLOGIA DE AFRODITE}

Existem diversos mitos que envolvem a deusa Afrodite e permeiam tanto o imaginário atemporal quanto a história da arte. Os textos que evocam tais mitos trazem, além da descrição física da deusa, traços de sua personalidade e de seus domínios, tão amplamente representados junto às suas figuras.

Um destes textos é o Hino Órfico 54 “À Afrodite”, que traz uma descrição ampla dos tópicos relacionados à deidade.

"Celeste, ilustre rainha de risada amorosa, nascida do mar, amante da noite [...] senhora produtora e noturna, dama que a todos conecta; teu é este mundo para se unir com harmonia, pois todas as coisas brotam de ti, ó poder divino. [...] toda a produção dos frutos da terra, e o alto-mar tempestuoso, a ti o balanço confessa e obedece a teu aceno [...]: Deusa do casamento, charmosa à visão, mãe dos Amores, que se delicia em banquetes; fonte de persuasão, secreta, rainha favorável, ilustremente nascida, [...] a mais desejada, doadora de vida, gentil [...]."

Sem dúvida um dos momentos mais lembrados pelos artistas visuais em suas obras é o nascimento de Afrodite, que pela Teogonia de Hesíodo, teria surgido das espumas do mar quando o falo de Urano caiu no oceano. Ela seria a metáfora para a união dos céus (Urano) com o mar, a fecundação dos céus no útero terreno, que é o oceano (CHEVALIER, 1982, p. 580). Uma segunda versão do nascimento de Afrodite afirma que ela é filha de Zeus e Dione, deusa ligada aos oceanos. Sendo Zeus uma das divindades ligadas aos céus, o mesmo simbolismo da ligação entre céu e mar ocorre nesta versão.

O Hino Homérico VI “A Afrodite” a descreveu fisicamente e acrescentou a continuação da primeira versão do nascimento da deusa que, ao sair dos mares, segue para a ilha de Cítera, onde é alegremente recebida pelas Horas e pelas Graças (estas associadas à Vênus pela relação com a beleza, aquelas trazem o vínculo à mudança de estações, que se ligam à Afrodite quando Ela traz a primavera). 
“Canto à Afrodite imponente, bela e coroada de ouro [...] [As Horas] a vestiram com trajes celestes: em sua cabeça colocaram uma coroa bem tecida de ouro, e em suas orelhas furadas elas penduraram ornamentos de oricalco e ouro precioso, e adornaram-na com colares dourados sobre seu suave pescoço e seus seios brancos como a neve [...]. E, quando elas a tinham plenamente enfeitado, elas a trouxeram até os deuses, que a saudaram em boas-vindas quando a viram, dando-lhe as mãos. Cada um deles pediu para levá-la para casa e torná-la sua esposa, de tão grandemente deslumbrados com a beleza da Citéria de coroa violeta."

A ampla gama de textos e referenciais sobre a deusa permitem acesso ao universo que a engloba e este acesso indubitavelmente foi explorado pelos artistas visuais em suas obras. Como veremos a seguir, estas descrições não engessaram os artistas à ilustração fiel da descrição de Afrodite, mas pelo contrário. Conforme o campo da arte foi cedendo seus moldes contidos ao figurativismo a figura de Afrodite acompanhou este processo, sendo representada de diversas formas, com diversos materiais e técnicas pelos artistas visuais.

\section{A CONSTRUÇÃO DA IMAGEM DE AFRODITE NA HISTÓRIA DA ARTE}

A história da divindade feminina associada à Afrodite vem desde antes do período paleolítico, época em que surge um dos primeiros registros de estatueta ritual, a Vênus Esteatopígia, que se refere a um ídolo feminino, com seios, abdômen, vulva, coxas e quadris grandes. A "Vênus de Willendorf" segue este padrão, que era amplamente associado à fertilidade da mulher e da natureza.

Num período posterior, já no contexto histórico da Grécia Clássica, há a concepção de Afrodite propriamente dita, que levaria mais do que somente a personificação de aspectos, levaria também personalidade, temperamento e características humanas (BULFINCH, 2014). Este é o período estimado para a criação da Vênus de Milo, que traria em si o ideal de beleza grego, que, também baseado na filosofia grega, traria a ideia de perfeição do corpo, mente e espírito ao mesmo tempo. 
Ademais, na Roma Antiga, Afrodite ganha a roupagem de Vênus bem como representações de sua nova faceta. Um dos afrescos encontrados em Pompeia mostra a deusa deitada numa concha, acompanhada pelo seu séquito de entidades e criaturas marinhas. Como seu epíteto "dourada" sugere, a divindade vem carregada de joias e símbolos de seu poder, como a coroa e o manto.

Dentro da cultura romana, Vênus ainda traria novas características de personalidade, bem como novas mitologias associadas ao seu nascimento como, por exemplo, aquelas colocadas por Apuleio, que sugere que a jovem deusa emerge das águas após ser gerada por Zeus e Dione, deusa dos oceanos. Vênus se ergue do mar (como sugere seu epíteto "anadiômene") e é acompanhada até a terra por um séquito de seres marinhos, tanto reais quanto mitológicos, e estes a coroam e a cobrem com mantos de seda.

Após o apogeu do cristianismo a imagem de Afrodite/Vênus se torna cada vez mais escassa, até o momento do retorno às origens helenistas no Renascimento, onde a figura da deusa é constante. A mitologia mais representada no Renascimento condiz com o mito proposto por Hesíodo na "Teogonia".

Uma das imagens mais marcadas na memória é o "Nascimento de Vênus" de Botticelli, que coloca a deusa sobre uma concha, acompanhada de um séquito de deuses que também a coroa e a ornamenta após sua saída do mar. Estes também a conduzem até a ilha de Cítera, onde ela faz nascer a primavera.

Posteriormente ao Renascimento e a retomada da temática da mitologia grega, é possível notar este mesmo tópico sendo reassumido no Rococó, especialmente em paisagens e cenas de galanteios, que fazem parte da natureza de Afrodite.

Neste caso, é possível ver que artistas como Watteau e Fragonard envolveram suas obras com a deusa, representando paisagens em Cítera, no caso de Watteau, e concebendo o surgimento da deusa pelo mar, no caso de Fragonard.

Durante o período Neoclássico o contato com a mitologia grega permanece, especialmente se tratando da figura da mulher. Afrodite, que é retratada por JeanAuguste Dominique Ingres, é vista em seu epíteto "anadiômene" cercada por querubins e cuidando de seus cabelos. 
Nas décadas após 1815, com o apogeu do que seria o academicismo francês, há pintores como William Adolphe Bouguereau e Alexandre Cabanel, que representaram o nascimento de Afrodite mesclado a uma paisagem marinha e maestria nas técnicas de naturalismo, dando-nos mais obras icônicas quando o tema é o nascimento da deusa.

No período seguinte às vanguardas artísticas, num momento já incluso no século XX, a ascensão da arte contemporânea desmantela a necessidade de um retorno ao academicismo, trazendo então uma visão inovadora sobre um tema tão antigo que é a mitologia grega.

Com esta abordagem Michelangelo Pistoletto traz em sua obra "Vênus dos Trapos", de 1967, a ótica da arte povera e da arte conceitual sobre a imagem da Vênus, que aqui é colocada de frente para uma pilha de roupas antigas e desgastadas, unindo o clássico nu feminino esculpido em mármore - carta marcada em diversos museus - à noção de algo deteriorado e abandonado, que seria a pilha de trapos.

No século XXI é possível notar diversas outras abordagens para a figura da Vênus. Uma delas é a solução proposta pelo museu "Staatliche Museen zu Berlin", na cidade de Berlin, na Alemanha no ano de 2016. A instituição propôs uma retrospectiva das imagens de Vênus e convida os visitantes a encarnarem o papel da deusa, se colocando sobre uma concha - muito semelhante ao quadro emblemático de Botticelli.

As interações realizadas pelo público foram diversas e enfatizaram diversas facetas de Afrodite, bem como houve propostas cômicas e inusitadas como, por exemplo, a presença de um cachorro ou um urso de pelúcia no lugar da deusa.

Praticamente todas entre estas representações da figura da deusa mostram-na nua, e este cenário é recorrente lidando com o corpo feminino, especialmente desta deusa, que sofre um processo de desintegração da sua imagem original - como deusa da fertilidade, possuidora do poder sobre todas as pessoas, já que ela intercederia por todas as relações afetivas que permeiam a experiência humana.

Este processo é descrito por Zsuzsanna Budapest, que afirma que a Deusa do amor e da sensualidade foi transformada em uma mera prostituta perante o olhar das religiões patriarcais - como era a própria religião grega, cujo Deus-Rei era um deus, não uma deusa - e que Afrodite - bem como outras deusas que regem os domínios de Afrodite, como Vênus, Lilith e outras - se torna a incorporação de tudo o que é o "mal" 
e ao feminino - aqui uma associação ao pecado e sua mitologia desenvolvida pelo cristianismo.

\section{A ICONOGRAFIA DE AFRODITE}

Dentro dos domínios de Afrodite existem diversos universos que se convergem na sua existência. Oceano, primavera, corpo, amor, prazer, sexo, soberania, ouro, beleza, e até mesmo batalhas são só o começo de seus aspectos. Porém, analisando cada um destes universos chega-se a ícones e símbolos constantes em suas imagens.

Define-se "ícone" um signo que mantém uma relação de semelhança com o objeto que ele caracteriza; enquanto o símbolo é um signo que se conecta a um significado determinado por convenção social. (PEIRCE, 1999, p. 66)

\section{Afrodite dos mares e das viagens marinhas}

No que se refere à relação da deusa com os mares, diversos epítetos são citados por Giuliana Ragusa. Dentre eles está o já citado "Anadiômene", e outros se acrescem, como "Euploia" (dos viajantes), "Limenitis" (dos portos), "Pontia" (do mar) e "Dionaia" (filha de Dione), por exemplo.

A matéria principal relacionada ao mar é, obviamente, a água, que traz uma noção de fertilidade, emoções, útero materno, fluxo, intuição. Além disso, é associado essencialmente à mulher em um ponto de vista grego (CHEVALIER, 1982, p. 20). O autor ainda comenta sobre o mar: "Símbolo da dinâmica da vida. Tudo sai do mar e tudo retorna a ele: Lugar dos nascimentos, das transformações e dos renascimentos." (IDEM, p. 592).

Presente em inúmeras imagens conectadas à deusa, a concha traz o significado de fecundidade e profundidade devido à sua associação ao órgão genital feminino, bem como seu vínculo à gestação, ao nascimento, à concepção. (IDEM, p. 270). 
A espuma marinha também teria em sua imagem a conexão com o esperma, convergindo ainda mais o simbolismo marinho para a reprodução humana. Afrodite, em seu nascimento narrado por Hesíodo, emerge das espumas marinhas.

Constantemente colocado como o animal que puxa a carruagem marinha de Afrodite, o golfinho evoca a noção de velocidade marítima e é tido como o senhor da navegação. (IDEM, p. 474). Ele ainda é um dos símbolos da antiga cultura Minoica, que seria um dos berços do culto à Afrodite (RAGUSA, 2005, p. 127).

Figuras míticas associadas ao mar também se relacionam ao séquito da deusa. Sereias, nereidas, náiades, tritões e toda a sorte de ninfas marítimas são constantemente representadas acompanhando Afrodite. Associadas aos perigos do mar, à beleza, às paixões, viagens e à sedução, estes seres estão quase completamente imersos nos domínios da deusa no que se refere aos seus simbolismos. (CHEVALIER, 1982, p. 814).

Dentro dos domínios das criaturas marítimas citadas no parágrafo anterior estão as ondas, que eram amplamente associadas aos cabelos das nereidas. As ondas ainda têm forte ligação com Afrodite ao serem vinculadas às inconstâncias, à mutabilidade e aos caprichos, características de personalidade continuamente encadeadas à Afrodite (IDEM, p. 658).

\section{Afrodite primaveril e dos bosques}

A deusa quando associada à estação das flores incorpora diferentes características. Embora algumas se assemelhem ao seu aspecto marítimo, como o de fertilidade, Afrodite engloba novos conceitos que estariam profundamente relacionados à renovação, juventude, energia e vida. Um de seus epítetos primaveris é “Antheia” (das flores).

As flores, relacionadas ao útero e à receptividade, são frequentemente fundidas a noção de primavera, período em que geralmente brotam. Estas também estão ligadas à feminilidade e à forma vulvar. (CHEVALIER, 1982, p. 438)

Safo, em seu fragmento $2 \mathrm{~V}$. tece um cenário completo visando invocar Afrodite por meio da persuasão. A poetisa escreve: 
“[...] templo sagrado onde agradável bosque de macieiras e altares nele são esfumeados com incenso. E nele água fria murmura por entre ramos de macieiras, e pelas rosas todo o lugar está sombreado, e das trêmulas folhas o torpor divino desce. E nele o prado pasto de cavalos viceja com flores e os ventos docemente sopram [...].”.

Este trecho deixa clara a associação de Afrodite aos bosques, que seriam uma representação máxima de vida, um dos domínios da deusa. Além disso, a religiosidade grega trazia a ideia de "témenos", que seria um bosque sagrado, onde rituais seriam conduzidos. (RAGUSA, 2005. p. 193-223).

O mito ainda cita que por onde Afrodite passava flores nasciam e a vida vicejava ao redor dela, reforçando ainda mais a associação da deusa às flores e à vida, unindo ambas à natureza. O trecho de Safo ainda retoma um símbolo já comentado - a água enfatizando ainda mais a relação entre natureza-Afrodite-fecundidade.

No mesmo fragmento ainda há algumas citações às macieiras. Sendo a maçã uma das frutas associadas à Afrodite, seria natural que a árvore de maçãs também tivesse tal relação com a deidade. Tanto que há registros de uma "Afrodite Meleia" (Afrodite das Maçãs) como epíteto da deusa. Dentro da tradição cristã a maçã teria correlação entre pecado e sabedoria, como colocado no mito de Adão e Eva, porém, para os pagãos a fruta associa-se à fertilidade, ao feminino, à vulva e ao amor, ou seja, profundamente conectado às esferas de Afrodite. (CHEVALIER, 1982. p. 572)

Dentre todas as flores que Afrodite Antheia tem domínio sobre, a rosa é a mais retratada entre elas. Um dos máximos símbolos vulvares, devido à sua semelhança física com o órgão genital feminino, a rosa está associada às ideias de beleza, fertilidade, prazer, romance, paixão. Além de tudo, a roseira com seus espinhos traz a metáfora das dores relacionadas ao amor e a noção de regeneração. (IDEM, p. 789).

\section{Afrodite como a rainha dos corpos e da beleza}

Antes de qualquer outro título Afrodite é a deusa do amor e da beleza, sendo assim naturalmente uma gama de imagens relacionadas a estes aspectos estariam conectadas à deusa. Dentre os epítetos que possuem símbolos explícitos na arte e 
evocam as características de amor e beleza em Afrodite estão Khrúsion (dourada), Poikilothrón (criado por Safo, significa “de flóreo manto furta cor”), Ambologera (a que vence a velhice), Bradínan (esguia). (RAGUSA, 2005)

O primeiro destes epítetos, Khrúsion, dá à deusa o adjetivo de "Dourada". Sendo o ouro um dos metais associados à Afrodite de acordo com a literatura clássica grega, a deidade é constantemente representada com coroas, brincos, colares, pulseiras e outras diversas joias douradas. Dentre o ouro de suas joias há também a presença constante de pérolas, associadas à Afrodite pela sua relação com o mar.

Constantemente vemos, em quadros principalmente, Afrodite representada com espelhos. Esta ligação associa a beleza à vaidade e as conecta a deusa, dando a ela mais um símbolo: o espelho. Porém, mais do que emblema da estética, o espelho é dito como o objeto que reflete os verdadeiros desejos da alma e revelar o oculto. (CHEVALIER, 1982, p 396). Aliado à Afrodite, o item seria um constante lembrete de que a deusa sabe o que há no coração e na alma dos humanos.

O espelho ainda é o principal símbolo da deusa, o "Espelho de Vênus" () que representa a mulher, o planeta Vênus, a deusa Afrodite. Diversas variações deste símbolo surgiram em meados dos anos 70 como símbolos de movimentos como o feminismo, e de organizações de mulheres como o movimento das mulheres lésbicas.

Já os epítetos "esguia" e "a que vence a velhice" podem ser atribuídos, dentro da arte, como características físicas da deusa, que é repetidamente caracterizada como uma mulher jovem e magra não só por conta de seus títulos, mas pelo olhar sobre o corpo feminino (chamado na década de 2010 de "male gaze" - olhar masculino) pelos artistas.

A autora Zsuzsanna Budapest comenta o quanto a imagem da deusa Afrodite se modificou desde seu primórdio como Vênus de Willendorf. Budapest afirma que as representações iniciais da deusa a colocavam como forte e robusta e ao decorrer do tempo ela foi se tornando cada vez mais lânguida, delicada, frágil, associada com processos de feminilidade. Suas poses passaram pelo mesmo processo, mostrando por fim uma Vênus inclinada, deitada, abaixada, usualmente colocada em posições de passividade e retirada de sua posição de assertividade inicial. 


\section{Afrodite e seu séquito na iconologia}

A literatura grega deixa claro que a deusa do amor é acompanhada por uma comitiva de seres mitológicos, bem como semideuses e até mesmo outros deuses. Nesta caravana mítica estão ninfas, sátiros, animais, querubins, as Horas, as Graças, o deus Zéfiro, e, em algumas ocasiões, seus amantes.

Ao ser acompanhada de seus companheiros amorosos em diversas representações e em mitos, fica clara a ideia de que nem mesmo a própria deusa do amor é imune a ele, e nem mesmo ela pode controlá-lo.

Zéfiro, as Horas e as Graças compõem o cortejo de recepção de Afrodite em seu nascimento. Zéfiro, deus dos ventos do oeste, sopra a espuma marinha e ergue Afrodite dos mares. Quando a deusa chega à Cítera, as Horas a recebem e a vestem, e as Graças a acompanham, por serem deusas ligadas à graça e à beleza elas estão imersas na esfera de Afrodite.

Já o caso das ninfas e dos sátiros, estes são regularmente postos como seres que vivem nos bosques festejando e cortejando os deuses (em geral Afrodite e Dionísio, por serem divindades relacionadas com os prazeres mundanos da paixão e do vinho). Sátiros, vinculados ao deus Pã, também têm correlação com a virilidade masculina, pertencendo assim à esfera de Afrodite.

Quanto aos querubins - que dentro do contexto pagão não seriam anjos, mas sim figuras aladas - a relação entre eles e Eros é imperativa. Como auxiliares do filho da deusa do amor eles observam os humanos e acompanham a deusa e seu filho em seu séquito. (BULFINCH, 2014).

\section{OS DESDOBRAMENTOS: AFRODITE NO SÉCULO XXI}

Tendo em vista os referenciais simbólicos da deusa é possível analisar se ela ainda é representada no século XXI; e, se é, como ela seria mostrada. Como esperado, o novo milênio trouxe novos métodos e técnicas para se associar à Afrodite. Com novas 
possibilidades - como quadrinhos, instalações, arte digital, performance - e antigas técnicas - pintura, escultura, desenho - a deusa ainda se mostra presente, mas sobretudo na cultura popular, onde é constantemente citada.

Uma das mais constantes associações à deidade neste século é com a música e a cultura que envolve cantoras do estilo pop. Vemos então, na década de 2010, a alusão à Afrodite com as performances de Kylie Minogue e Lady Gaga. A primeira, australiana com carreira estabilizada desde a década de 1980, lança em 2010 o álbum "Aphrodite", com canções que citam a temática amorosa, que pertence à esfera da deusa.

A cantora, em sua turnê "Aphrodite Live" ainda personifica a deusa em vários de seus concertos (figura 1), evocando seus símbolos e associações, como por exemplo, o dourado, a concha, a coroa e o séquito. A cantora, na mesma turnê, interage com bailarinos vestidos com asas, referenciando assim o Cupido e o cortejo de querubins (figura 2).

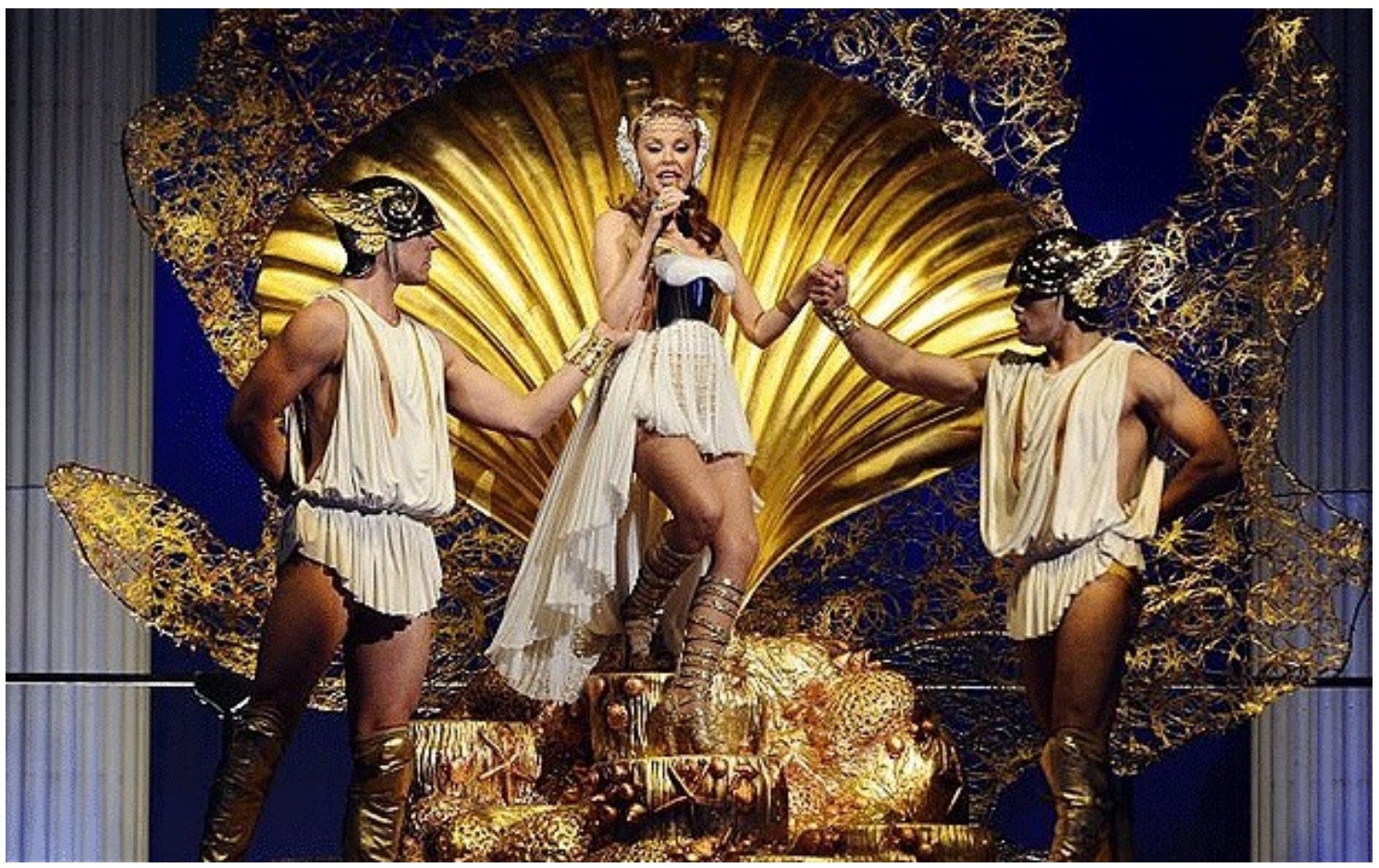

Figura 1: Kylie Minogue em sua turnê “Aphrodite Tour”. Fonte: Telegraph.uk 


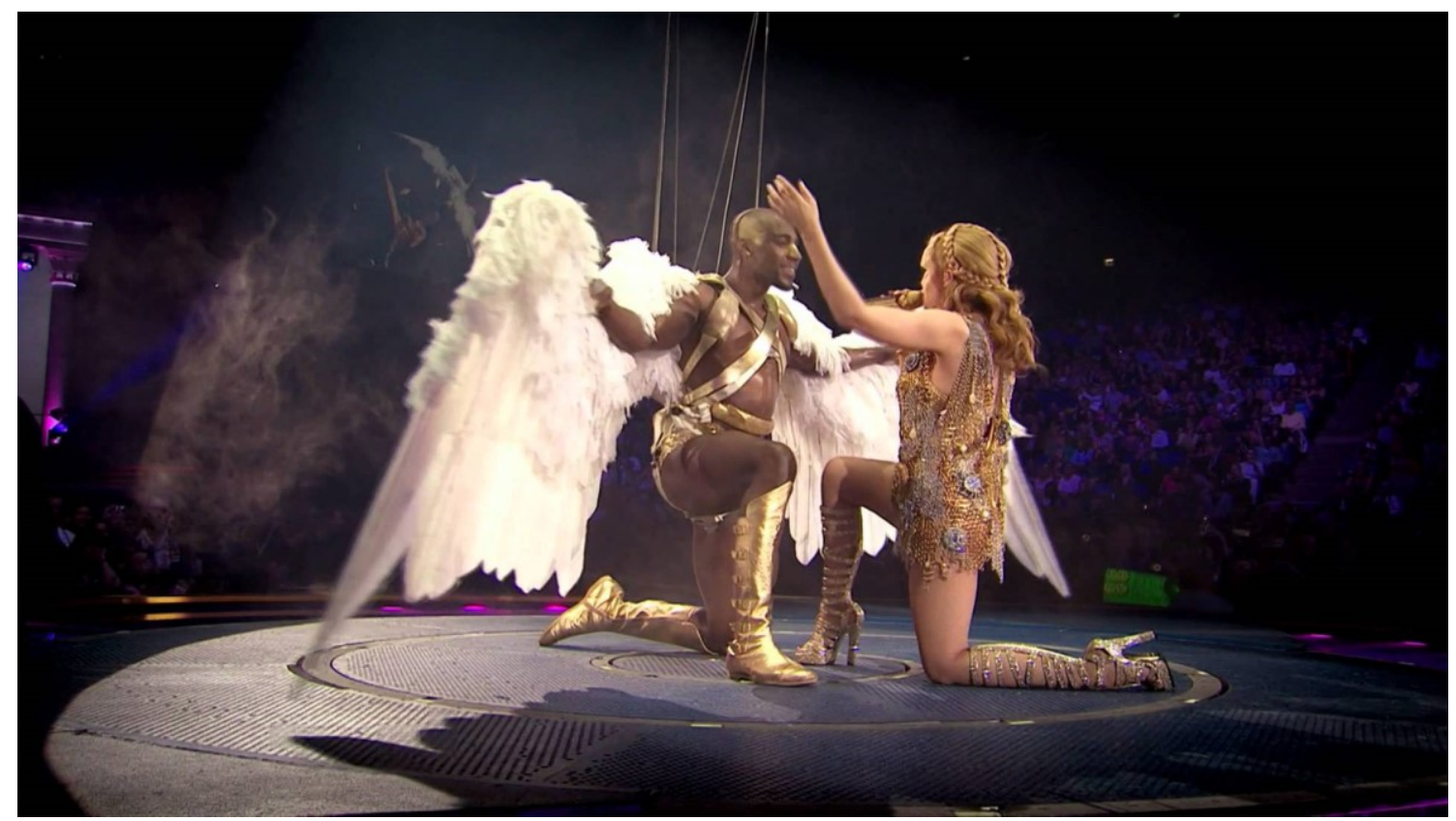

Figura 2: Kylie Minogue em sua turnê “Aphrodite Tour”. Fonte: Youtube.com

Além de Kylie Minogue, a cantora estado-unidense Lady Gaga também mencionou a deusa grega do amor em seu álbum "ARTPOP” (2012). O álbum todo é baseado na fusão entre cultura popular e o campo da arte. Sendo assim, a cantora utilizou a imagem do famoso "Nascimento de Vênus" de Botticelli na arte da capa do álbum (figura 3), fazendo ainda outras referências artísticas utilizando estátuas de mármore, uma das obras de Jeff Koons, entre outras.

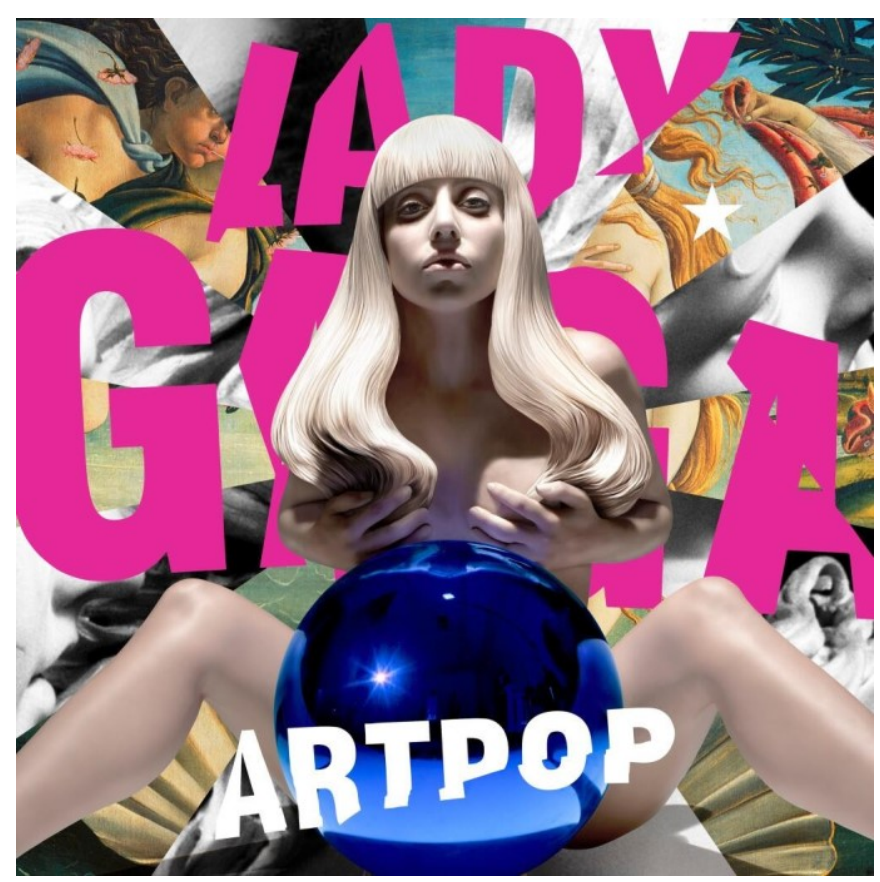

Figura 3: Capa do álbum “ARTPOP” (2012) de Lady Gaga. Fonte: MTV.com.br 
A cantora cita a deusa mais vezes, especialmente na música "Venus" do álbum já citado. No videoclipe da mesma música, chamado “An ARTPOP Film” muitas analogias à mitologia grega são feitas. A artista, representando-se ferida por flechas, é resgatada nas portas do que seria uma referência a um templo de Afrodite. Dentro do templo, a cobrem com um véu feito de flores - citação à Afrodite Antheia (das flores) e a mergulham numa piscina, mencionando o nascimento da deusa (figura 4).

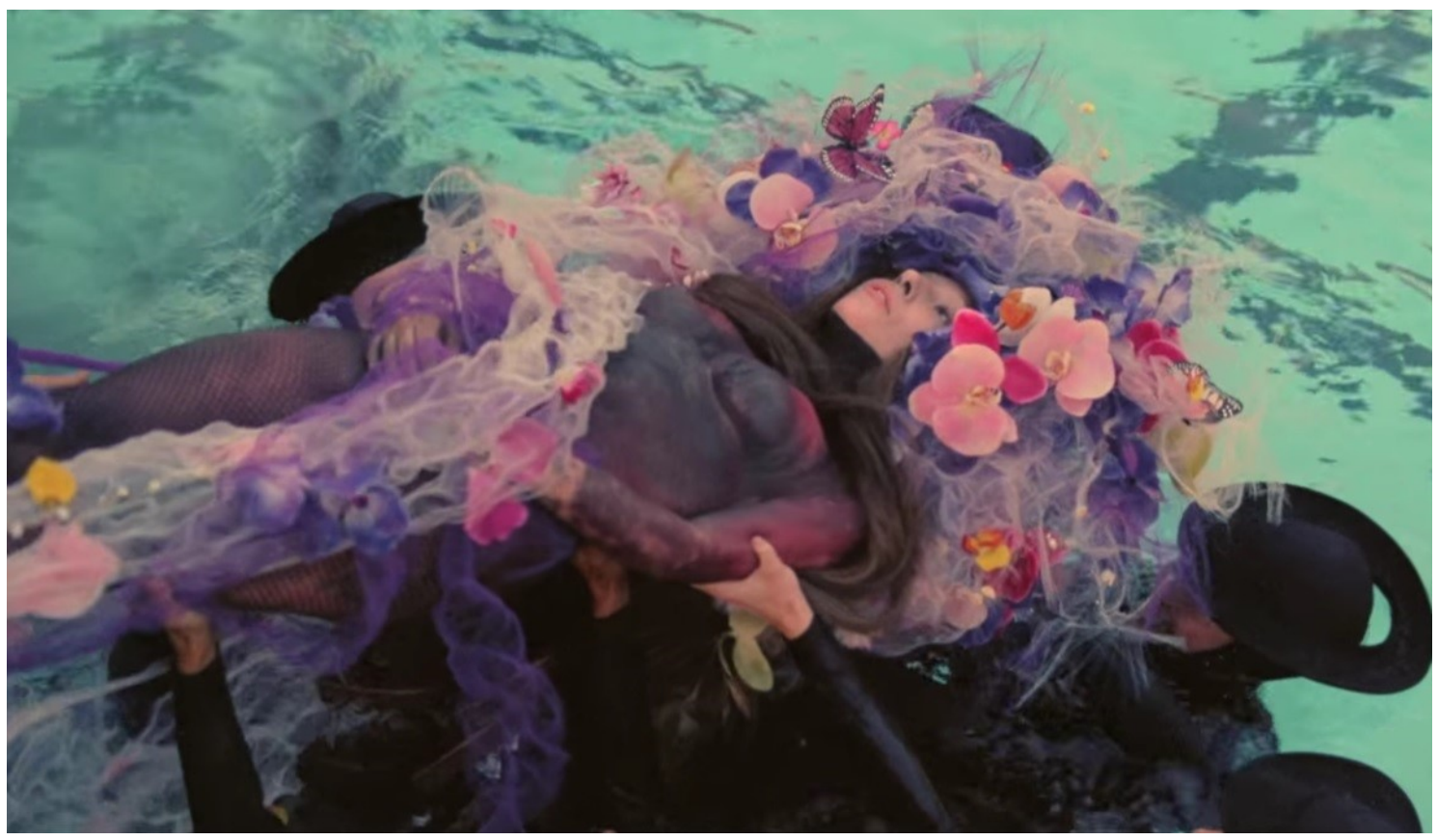

Figura 4: Lady Gaga sendo imersa na água com um véu de flores. Fonte: Youtube.com

As menções à deusa do amor chegam ainda na turnê "ArtRave" da artista, que personifica Afrodite (figura 5) através de seu figurino, que também se conecta com trechos de sua canção já citada. Vestindo um biquíni de conchas, ela canta "Mulher Afrodite, biquíni de conchas, calcinha de flores, Vênus" (tradução livre).

\section{CONCLUSÃO}

Afrodite é somente um dos casos de atemporalidade em relação à sua imagética e também sua esfera. $\mathrm{O}$ amor, a beleza e outros atributos de Afrodite se modificam com o tempo, mas não deixam de habitar $\mathrm{o}$ imaginário e o cotidiano popular. 


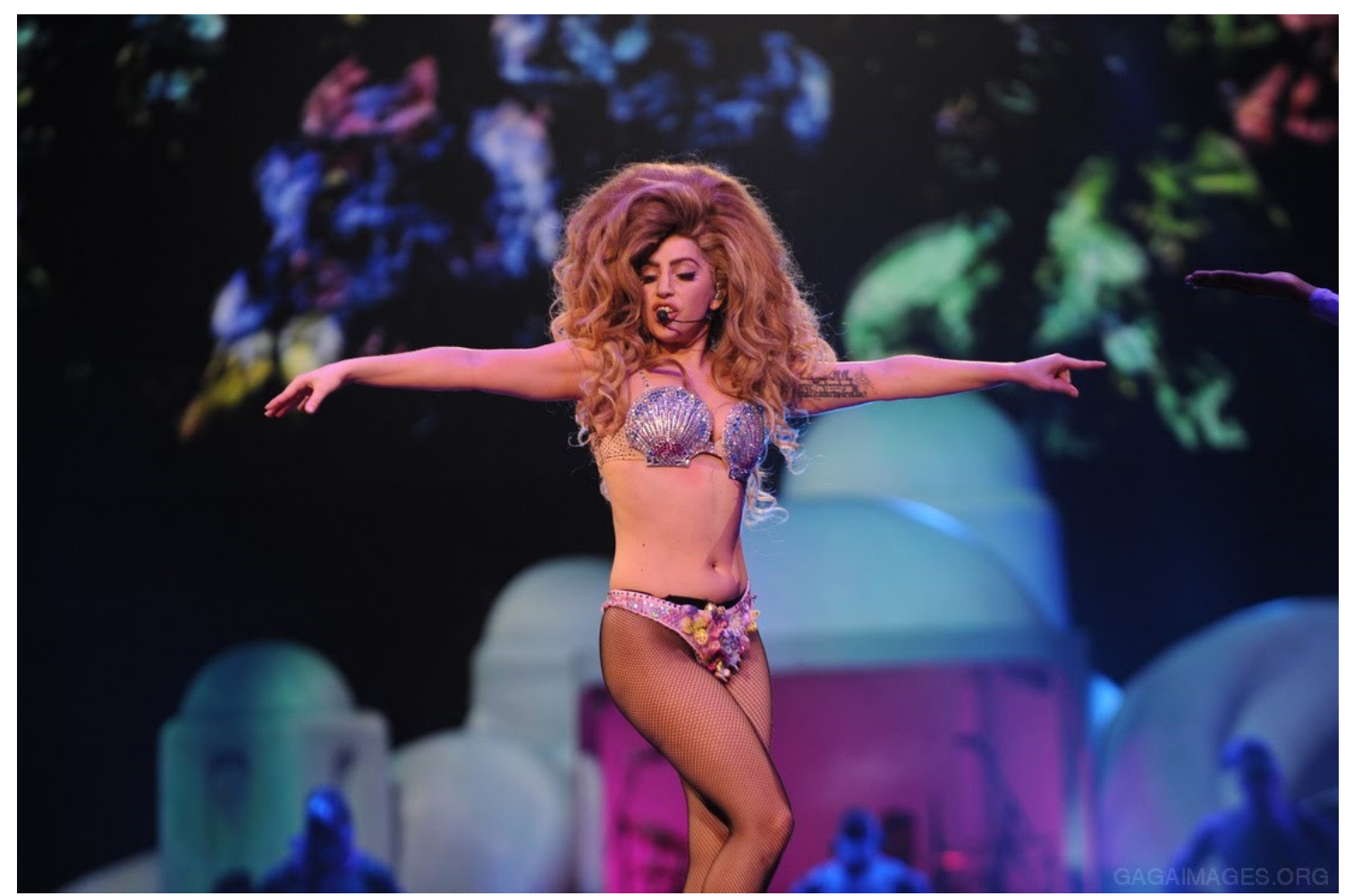

Figura 5: Lady Gaga em sua turnê "ArtRave”. Fonte: Youtube.com

É visível a importância de Afrodite dentro da história da arte. Um conjunto visual que a evoca já existe no imaginário das pessoas, e isso permanece até o século XXI, em que os mesmos símbolos e a mesma mitologia são resgatados e utilizados em novas mídias.

A citação à mitologia grega e o conhecimento de seus nuances e detalhes chegaram no campo da arte e o superaram, chegando no campo da cultura popular e por fim mesclando os dois, fazendo com que haja uma grande acessibilidade ao repertório da arte via cultura popular e vice versa. Citando aqui a própria Lady Gaga, "a cultura popular estava na arte, agora a arte está na cultura popular.” 


\section{REFERÊNCIAS}

BUDAPEST, Zsuzsanna. The Holy Book of Women's Mysteries. 2007. Red Wheel/Weiser. $3^{\text {a }}$ edição. San Francisco, California.

BULFINCH, Thomas. O livro da mitologia. 2014. Editora Martin Claret. $5^{\text {a }}$ edição. São Paulo, São Paulo.

CHEVALIER. Jean. Dicionário de Símbolos. 2015. Editora José Olympio. $28^{\mathrm{a}}$ edição. Rio de Janeiro, Rio de Janeiro.

GERMANOTTA. Stefani. "Venus". In.: ARTPOP. Interscope, c2013. 1 CD. Faixa 2 (3 $\min 54)$.

PEIRCE, C.S. Semiótica. 1999. $3^{\text {a }}$ edição. Editora Perspectiva. São Paulo, São Paulo RAGUSA, Giuliana. Fragmentos de uma deusa: A representação de Afrodite na lírica de Safo. 2005. Editora Unicamp. $1^{a}$ edição. Campinas, São Paulo.

Hinário de Afrodite - Helenos. Disponível em $<$ http://www.helenos.com.br/Home/hinario/Afrodite>. Acesso em 17 de outubro de 2016.

Theoi - Aphrodite. Disponível em <http://www.theoi.com/Olympios/Aphrodite.html $>$. Acesso em 17 de outubro de 2016. Original em Inglês. 